See discussions, stats, and author profiles for this publication at: https://www.researchgate.net/publication/311626082

\title{
TerminoCLIL: A Terminology-based Approach to CLIL
}

Article in LCM - La Collana / The Series · December 2016

DOI: 10.7359/791-2016-silv

2 authors:

Manuel Moreira Silva

Polytechnic Institute of Porto

50 PUBLICATIONS 88 CITATIONS

SEE PROFILE

exandra Albuquerque

Polytechnic Institute of Porto

32 PUBLICATIONS 36 CITATIONS

SEE PROFILE

Some of the authors of this publication are also working on these related projects:

Project $\quad$ SPACE network View project

POLISSEMA (ISCAP Journal of Letters) - CfP 2020 View project 


\title{
TerminoCLIL: \\ A Terminology-based Approach to CLIL
}

\author{
Manuel Silva - Alexandra Albuquerque
}

doi: 10.7359/791-2016-silv

Keywords: CLIL, specialised knowledge, TerminoCLIL, terminology, terminology-based approach.

\section{INTRODUCTION}

Considering the new European educational context deriving from the Bologna Process, the urgency of improving university students' Foreign Languages (FL) competences and the unsatisfactory results of present-day methodological approaches to FL teaching and learning, it seems that the ground is, as Morgado and Coelho (2012) state, ripe for new perspectives in this area.

CLIL appears as one of these approaches - more content oriented, more able to meaningfully integrate language and content and to lead to the desired FL proficiency and pluricultural learning outcomes. It is also based on a new paradigm: that of the language user, rather than the language learner (Moore and Dooly 2010).

In the context of higher education in Portugal, HEIs are still in the process of beginning the implementation of a CLIL approach. There is almost no experience with CLIL and little or no research has been developed to support its introduction, spread and use. The reason for this also lies in CLIL being an area that has only recently been more thoroughly explored for appropriate use at higher levels of education. To change this situation, ReCLes.pt (Network of Language Centers in Higher Education in Portugal) members are striving to make up for the paucity of research in this area. For this purpose ReCLes created a national program for training content teachers in Portuguese higher education to best learn and apply essential concepts of English-mediated instruction, integrating classroom management, scaffolding, learner autonomy, Web 2.0 tools and terminology-based learning activities. 
Based on a national project promoted by ReCLes.pt, seven HEIs prepared the groundwork for subject classes to be taught in English. To carry out this innovative national project, a needs analysis of the higher education institutions in Portugal was first prepared for the ICLHE (Integrating Content and Language in Higher Education) 2013 Conference in Maastricht. The results, including quantitative data and interviews with administrators and subject teachers in the participating HEI, have corroborated the urgent call for CLIL in HEI and have led to the development of a training manual, written collaboratively by seven polytechnics, as part of the CLIL project (Morgado et al. 2015). This project is divided into three stages:

i. $1^{\text {st }}$ Stage - Explored how foreign languages were taught within Portuguese HEIs and whether there was a linguistic policy, as well as the perceptions of governance and teaching staff on their foreign language skills needs and those of their students.

ii. $2^{\text {nd }}$ Stage - Focused on creating a CLIL learning community in higher education institutions through the ReCLes network, and to collaboratively write a CLIL course manual for trainers, stating its philosophy, methods, skills, content-based approaches, genres, tools and implementation.

iii. $3^{\text {rd }}$ Stage - Devoted to implementing the CLIL modules and courses in several HEIs, and to monitoring the experience through similar data collecting tools among all participating institutions (Morgado et al. 2012).

During the development of this project (from September 2012 to March 2015) and after a state of the art analysis, we felt the need to bring in new perspectives and approaches that would better fit the context and the needs of higher education teachers and students. One of the approaches that was thought to better suit these needs was the terminological approach, as terminology focuses on the collection, description, processing and systematic representation of concepts in a specialised domain. The use of terminology appeared, in our view, as a key construct in CLIL teaching, as it involves the search, production, use and dissemination of information. Bearing this in mind, it was decided to conceive a terminology-based approach to fit CLIL specific teaching and learning environments and workflows, which is now presented. 


\section{Some words ABout CLIL}

CLIL may stem from LSP practices, but goes beyond them and raises awareness that language changes according to its contexts of use, i.e. it has specific communication purposes, making use of a domain-specific language. Moreover, successful CLIL requires teachers of different subject fields to engage in alternative ways of planning their teaching for effective learning, not only as far as the specific domain of knowledge is concerned, but also bearing in mind the best way to use language as a knowledge carrier.

A CLIL environment is flexible and there are many different strategies, models and approaches that can depend on a range of contextual factors (Coyle 2008). Whatever the approach, it is, however, a major issue that the content on the topic or theme leads the way. In fact, it could be said that one of the critical features that differentiates CLIL from LSP is that in the former content is new, relevant and cognitively challenging. Thus, CLIL is not language teaching enhanced by a wider range of content (knowledge). Neither is it content teaching translated into a different language (code) from the mother tongue. These considerations constituted the ground for the development of the methodology proposed in this chapter.

\section{AN INTEGRATED TERMINOLOGY-BASED APPROACH TO CLIL}

As suggested above, CLIL is an approach for learning content through an additional language (foreign or second) and terminology is dedicated to the scientific study of concepts and terms used in specialised languages and to their structuring in specialised knowledge representation systems. Thus, both subject and the language are important elements of the CLIL environment and of terminology.

Terminology plays a crucial role in the development of communication processes as well as in information and knowledge sharing, which has led us to consider the need to create a methodology that specifically addresses its use in CLIL environments. In fact, when a field is truly new to students, their first contact with this reality will be through terms, either when listening to the CLIL teacher or when reading class material on their own. They will then have to learn how to recognise terms related to the domain specific information and organise them in a meaningful way. 
A terminological approach to CLIL - or TerminoCLIL - enhances the mutual beneficial dialogical relation between CLIL and terminology, which is the link between two crucial dimensions of both fields: (1) knowledge and competences (concepts and expertise) and (2) language (discourse on the knowledge). Together, these dimensions can result in non-ambiguous and more efficient communication about specialised knowledge since there is no term (language) without a concept (knowledge) and vice versa. Therefore, some of the aims of terminology are to organise, structure and classify discourse (linguist) and knowledge (expert).

Due to the extra-linguistic nature of knowledge, it is generally through discourse that knowledge and its representations are reached. Knowledge, which can be organised by both students and experts as they construct their own competences, is always transferred by a verbal or non-verbal text. Terms are, thus, the privileged means to represent knowledge and the relation between Concept, Text, and Term (see Fig. 1).

The texts prepared by CLIL teachers are aimed at the transmission/ acquisition of knowledge and competences. The new reality in a foreign language (FL) increases the need to anchor this knowledge in an organised discourse or text or a corpus of relevant texts. Terms can be extracted from texts and become those anchors.

The terminology-based approach to CLIL, whose high-level representation is displayed in Figure 2, is divided into three stages: (1) Knowledge Retrieval / Organisation, (2) Knowledge Application and (3) Knowledge Visualisation, and follows Bloom's taxonomy, being based on a scaffolded learning process. The approach integrates contributions from Knowledge Management, Terminology Activity and Learning Objectives as defined by Bloom (1956).

It is our view that in the CLIL learning environment, with strong linguistic and extra-linguistic input, terms (at the discourse level) will allow students to more easily access and acquire knowledge and competences. These will then be further elaborated as they use that knowledge, through a scaffolded process of different, but connected stages and steps, which we have divided into four categories: Actions, Outcomes, Questions and Tools, as described in the following Learning Activity Plans (see Tabs. 1, 2 and 3 ).

During the development of these plans, we propose a set of defined learning objectives according to Bloom's (1956) taxonomy. These objectives are defined taking into consideration the different activities and the communicative and cognitive skills to be developed or enhanced during the various stages, which are now described briefly. 


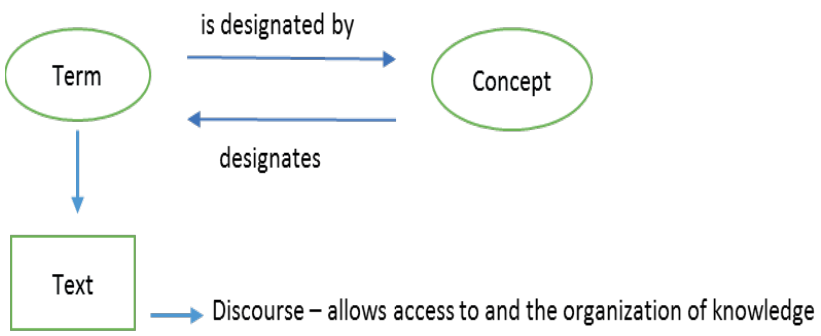

Figure 1. - Relation between Concept, Text, and Term.

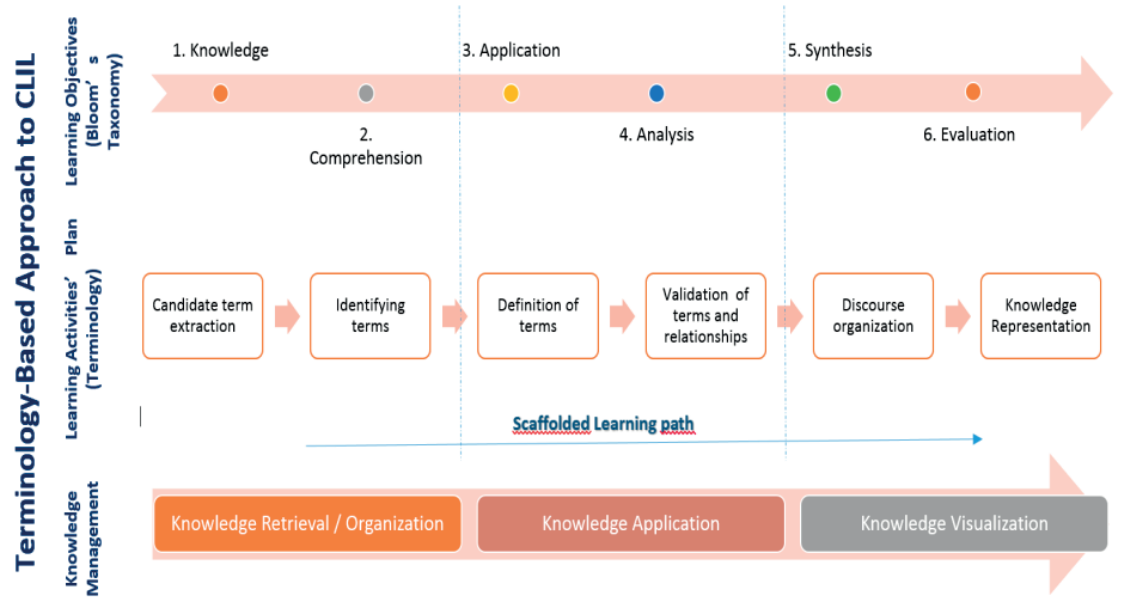

Figure 2. - Integrated terminology-based approach to CLIL bigh-level representation.

\subsection{Stage 1: Knowledge Retrieval / Organisation}

This stage involves recalling information, observing reality in the field of knowledge and finding/extracting information in/from texts. Teachers can develop their activity by following the Actions, Questions, Tools and Outcomes described in the Learning Activity Plan proposed for this stage, as described in Table 1. 
Table 1. - Learning Activity Plan based on Bloom's Taxonomy (Stage 1).

\begin{tabular}{|c|c|c|c|}
\hline \multicolumn{4}{|c|}{ KnOWledge Retrieval / ORganisation } \\
\hline \multicolumn{2}{|l|}{ Knowledge } & \multicolumn{2}{|l|}{ Comprehension } \\
\hline \multicolumn{2}{|c|}{ Recall of information, observation } & \multicolumn{2}{|c|}{ Finding information from the text } \\
\hline \multicolumn{2}{|l|}{ Identifying terms } & \multicolumn{2}{|l|}{ Textual match } \\
\hline Actions & Outcomes & Actions & Outcomes \\
\hline Identifying terms & $\begin{array}{l}\text { List of (candidate) } \\
\text { terms }\end{array}$ & Classifying & Collection \\
\hline Finding terms & Quiz & Comparing & Explanation \\
\hline Selecting terms & & Exemplifying & List \\
\hline Extracting terms & & Inferring & Quiz \\
\hline Questions? & Tools & Questions? & Tools \\
\hline What is [term]? & $\begin{array}{l}\text { http://taws.tilde. } \\
\text { com/plaintext }\end{array}$ & $\begin{array}{l}\text { How would } \\
\text { you distinguish } \\
\text { between a generic } \\
\text { and a specific term? }\end{array}$ & Visual Thesaurus \\
\hline $\begin{array}{l}\text { What is the } \\
\text { definition? }\end{array}$ & $\begin{array}{l}\text { http://www.nactem. } \\
\text { ac.uk/software/ } \\
\text { termine/ }\end{array}$ & $\begin{array}{l}\text { Can you establish } \\
\text { a relation between } \\
\text { some of the terms? }\end{array}$ & $\begin{array}{l}\text { http://www.clres. } \\
\text { com/semrels/umls_ } \\
\text { relation_list.html }\end{array}$ \\
\hline \multirow[t]{6}{*}{$\begin{array}{l}\text { Complementary } \\
\text { information }\end{array}$} & $\begin{array}{l}\text { http://termostat. } \\
\text { ling.umontreal.ca/ }\end{array}$ & \multicolumn{2}{|c|}{$\begin{array}{l}\text { Can you describe the connection between } \\
\text { the terms? }\end{array}$} \\
\hline & & \multicolumn{2}{|c|}{ Can you identify the concept? } \\
\hline & & \multicolumn{2}{|c|}{ Can you illustrate the terms? } \\
\hline & & \multicolumn{2}{|c|}{ Can you name synonyms/antonyms? } \\
\hline & & \multicolumn{2}{|c|}{ Can you find a definition? } \\
\hline & & \multicolumn{2}{|c|}{ Can you link concept/term? } \\
\hline
\end{tabular}

When given a specialised source text, students will try to recognise both known and new concepts to understand the new reality better. However, when the field is entirely new to them, their first contact with this reality will be through terms, either when listening to the CLIL teacher or when reading class material on their own. They will then have to learn how to recognise terms related to the domain specific information and organise them in a meaningful way. With the CLIL teacher, they can initially use an extraction tool and then refine the search and gather more information. By extracting and listing all possible terms, definitions and other relevant terminological information from the texts, students will find and establish relations between domain concepts and can begin to organise some of them in order to make sense out of the new domain and structure knowledge about it in a semi-formal manner. 


\subsection{Stage 2: Knowledge Application}

At this stage, students will use knowledge in a new situation to be examined in detail in Table 2.

Table 2. - Learning Activity Plan based on Bloom's Taxonomy (Stage 2).

\begin{tabular}{|c|c|c|c|}
\hline \multicolumn{4}{|c|}{ KNOWLEDGE APPLICATION } \\
\hline \multicolumn{2}{|l|}{ Application } & \multicolumn{2}{|l|}{ Analysis } \\
\hline \multicolumn{2}{|c|}{ To use in a new situation } & \multicolumn{2}{|l|}{ To examine in detail } \\
\hline \multicolumn{2}{|l|}{ Definition of terms } & \multicolumn{2}{|c|}{ Validation of terms and their relationships } \\
\hline Actions & Outcomes & Actions & Outcomes \\
\hline Implementing & Demonstration & Integrating & Term base \\
\hline Executing & Texts & Analysing & Glossary \\
\hline Translating & Presentation & Structuring & Terminology file \\
\hline Using & Simulation & Organising & \\
\hline Questions? & Tools & Questions? & Tools \\
\hline $\begin{array}{l}\text { How would you use } \\
\text { this terminology } \\
\text { to describe graphs, } \\
\text { images, or tables? }\end{array}$ & $\begin{array}{l}\text { https://www. } \\
\text { wordnik.com } \\
\text { http://www. } \\
\text { onelook.com/ } \\
\text { http://www. } \\
\text { wordsense.eu }\end{array}$ & $\begin{array}{l}\text { Can you make } \\
\text { a distinction } \\
\text { between contexts/ } \\
\text { communication } \\
\text { levels...? }\end{array}$ & Advanced search \\
\hline \multicolumn{2}{|c|}{ Which context is the most suitable? } & $\begin{array}{l}\text { How would you... } \\
\text { select relevant terms? }\end{array}$ & $\begin{array}{l}\text { Textual corpus } \\
\text { analysis } \\
\text { Concordance } \\
\text { analysis }\end{array}$ \\
\hline \multicolumn{2}{|c|}{ Can you formulate a definition of a term? } & $\begin{array}{l}\text {... distinguish } \\
\text { between domain } \\
\text { (un)suitable terms? }\end{array}$ & $\begin{array}{l}\text { http://www. } \\
\text { webitext.com/ } \\
\text { bin/webitext.cgi }\end{array}$ \\
\hline \multirow{2}{*}{\multicolumn{2}{|c|}{$\begin{array}{l}\text { Can you find an equivalent } \\
\text { in Portuguese? }\end{array}$}} & $\begin{array}{l}\text {... rate the exactness } \\
\text { of the terms that } \\
\text { designate the concept? }\end{array}$ & $\begin{array}{l}\text { http://www. } \\
\text { tradooit.com/ }\end{array}$ \\
\hline & & ... define the concept? & $\begin{array}{l}\text { http://corpora. } \\
\text { ids-mannheim. } \\
\text { de/ccdb/ } \\
\text { http://www. } \\
\text { webitext.com/ } \\
\text { http://www. } \\
\text { termbases.eu/ }\end{array}$ \\
\hline
\end{tabular}


Students are expected to be more aware of the knowledge field and to link (at least some of the) terms with concepts. They will also be more aware of synonyms, polysemy, and levels of language and probably begin to discover that the use of terms is context-linked: to issues of who is speaking or writing, to the level of knowledge involved, and to the purpose of the given communication. Moreover, since they are accessing knowledge in a foreign language, students will frequently be tempted to find equivalents in their mother language. This can be a challenging exercise because concepts and terms do not necessarily map easily across languages. The association of term meanings from different languages to corresponding concepts raises the problem that the terms used to designate a particular concept in the conceptual system may not have a match either in the textual representations of the domain or in the different classification systems and taxonomies.

CLIL teachers will have to provide language-independent frameworks of information (e.g. images), since differences in language, culture and conceptualisation must be explained, known, and understood before a multilingual term base/glossary can be built. This will help students not only organise their knowledge with cultural awareness, but also define terms and correctly present specialised information in multilingual contexts.

\subsection{Stage 3: Visualising Knowledge}

At this stage, students who organise discourse and represent their knowledge to acquire specialised knowledge are expected to understand reality from an expert point of view (Tab. 3).

Texts continue to be important, but they will be an outcome instead of being simply a starting point (as in stage 1) or a bottom-up method to access knowledge. Since most of the relations between concepts have been refined and validated with the CLIL teacher (expert), students will be able to represent domain knowledge (top-down) in at least two ways:

i. In a concept map (see Fig. 3) - for instance, domain knowledge can be represented by using electronic tools and the semantic relations previously studied.

ii. Building glossaries - an engaging but demanding task that provides an opportunity for students to better understand new concepts, the way they relate to each other and their position in the overall knowledge structure of the new domain. 
TerminoCLIL: A Terminology-based Approach to CLIL

Table 3. - Learning Activity Plan based on Bloom's Taxonomy (Stage 3).

\begin{tabular}{|c|c|c|c|}
\hline \multicolumn{4}{|c|}{ KNOWLEdGE VISUALISATION } \\
\hline \multicolumn{2}{|l|}{ Synthesis } & \multicolumn{2}{|l|}{ Evaluation } \\
\hline \multicolumn{2}{|c|}{ To change or create something new } & \multicolumn{2}{|c|}{$\begin{array}{l}\text { To make judgments according } \\
\text { to standards }\end{array}$} \\
\hline \multicolumn{2}{|c|}{$\begin{array}{l}\text { Discourse organisation } \\
\text { and Knowledge representation }\end{array}$} & \multicolumn{2}{|c|}{ Specialised knowledge } \\
\hline Actions & Outcomes & Actions & Outcomes \\
\hline Designing & $\begin{array}{l}\text { Visual Conceptual } \\
\text { Map }\end{array}$ & Solving & $\begin{array}{l}\text { Content acquisition } \\
\text { through } \\
\text { terminological } \\
\text { units and semantic } \\
\text { relations }\end{array}$ \\
\hline Constructing & $\begin{array}{l}\text { Multilingual maps } \\
\text { and texts }\end{array}$ & & $\begin{array}{l}\text { Effective } \\
\text { communication } \\
\text { (context, level } \\
\text { of language, } \\
\text { knowledge transfer) }\end{array}$ \\
\hline Planning & & & $\begin{array}{l}\text { Cognition } \\
\text { development (lower } \\
\text { and higher order) }\end{array}$ \\
\hline Making & & & $\begin{array}{l}\text { Culture awareness } \\
\text { (through language } \\
\text { management } \\
\text { and translation) }\end{array}$ \\
\hline $\begin{array}{l}\text { Questions about } \\
\text { your glossary } \\
\text { or database }\end{array}$ & Tools & Questions? & Tools \\
\hline $\begin{array}{l}\text { Which template/ } \\
\text { model would you } \\
\text { use to build it up? }\end{array}$ & http://cmap.ihmc.us/ & $\begin{array}{l}\text { Based on what } \\
\text { you know, } \\
\text { how would } \\
\text { you explain...? }\end{array}$ & Surveys \\
\hline $\begin{array}{l}\text { Which levels } \\
\text { and fields would } \\
\text { you suggest? }\end{array}$ & $\begin{array}{l}\text { http://www. } \\
\text { mindmeister.com/pt }\end{array}$ & $\begin{array}{l}\text { Has terminology } \\
\text { helped you increase } \\
\text { your knowledge } \\
\text { of the field } \\
\text { of studies? }\end{array}$ & Tests \\
\hline \multicolumn{2}{|c|}{$\begin{array}{l}\text { Can you propose a (new) translation } \\
\text { of the terms? }\end{array}$} & \multicolumn{2}{|c|}{ Do you agree with the actions/outcomes? } \\
\hline
\end{tabular}

Provided that the learning process was initiated as or has included a multilingual approach, these activities can be carried out both in a FL and in the mother tongue. 
In the CLIL classroom, with a foreign language as the means of communication and the source of terminology, CLIL teachers and students need to understand the complexity of the field of study and the semantic diversity required for expression; then, they must find a method to represent the domain. Concept maps can thus be used for the analysis, structuring, and spread of specialised knowledge. As an effective means of representing and communicating knowledge, concept mapping is a process of visually linking concepts with propositions. The concepts constructed are enclosed in shapes and propositions of (semantic) relationships among the concepts are indicated by linking words. When concepts and linking words are carefully chosen, these maps can be useful classroom tools for observing nuances of meaning, helping students organise their thinking, and summarising subjects of study.

Concept maps support knowledge representation, both individually and collaboratively, and promote more efficient knowledge sharing. They help to visually and graphically access and represent domain-specific information, knowledge, and competences. They are the backbone of a discovery-learning environment, where students can first draw a concept map of the information they have learned or gathered on a specific topic, share their concept maps with the group, and finally consider other examples of peer work and suggestions for analysing them, offering constructive criticism, diagnosing misunderstandings and restructuring the information with the help/validation of the teacher.

In this way, these cognitive tools complement the learning process, as is illustrated in the following example, where a marketing plan is mapped out into its multiple concepts (Fig. 3) extracted from a text.

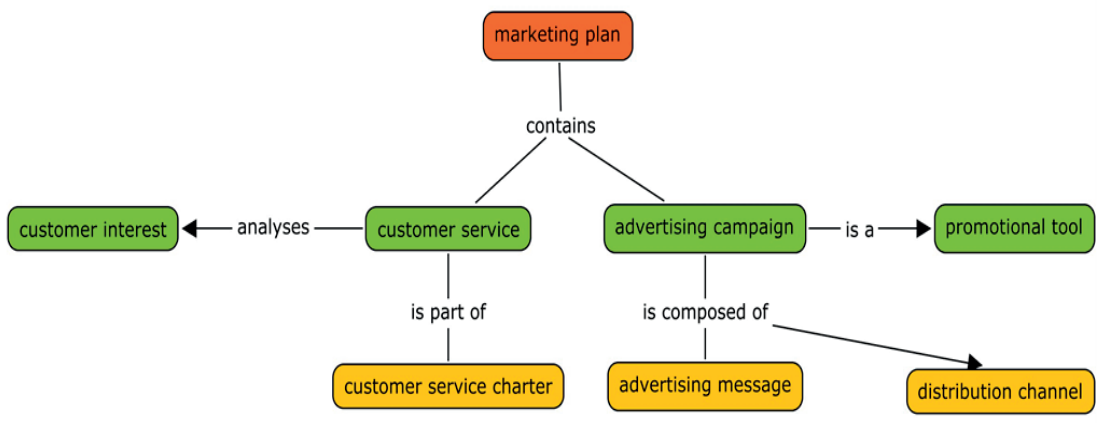

Figure 3. - Example of concept map elaborated upon text extraction. 
Students' creation of concept maps provides effective feedback on the their understanding of domain knowledge and competences through semiformal knowledge representations. The degree of complexity increases when concept maps are used to develop a multilingual representation. To avoid any distraction from comprehension of the workflow and of the different tasks proposed, the different steps required must be clearly defined and explained. Monitoring of the students throughout the entire cycle of the process contributes to enhancing and supporting the scaffolded learning path.

The active participation of the expert (teacher) contributes to resolving problems that are:

i. conceptual - knowing the domain can help to avoid ambiguity and increase their semantic precision;

ii. linguistic - familiarity with the specialised language and recognition of most of the terms to be used in different languages will speed up the time needed to find the proper equivalent;

iii. pragmatic - awareness of the use of the term and its acceptance by peers can make it easy to understand and anticipate meaning based on the context.

The CLIL teacher can apply the terminology-based approach described and proposed here, but the starting point for the students will be the CLIL texts proposed within a bottom-up learning approach. Note that, in a contrasting top-down learning approach, the CLIL teacher (expert) must validate all knowledge acquisition at every stage. In order to accomplish the objectives of acquiring specialised knowledge, CLIL teachers can adapt and reorganise the Learning Activity Plans that cover learning objectives connected to Bloom's (1956) Taxonomy, terminology activities, and related tools as proposed in Tables 1, 2 and 3.

\section{Concluding Remarks}

This terminology-based approach to CLIL, and the entire "theoretical and practical basis for the creation of a CLIL Learning Community of foreign language teachers and subject teachers" (Silva et al. 2015) were tested in training courses offered to domain-specific teachers in all the institutions involved in the project. Although no assessment tool has been applied as yet, feedback from those teachers involved is enthusiastic and motivating.

Revisiting terminology as a tool that promotes and supports CLIL learning environments is certainly uncovering new learning paths that 
have yet to be sufficiently explored. Moreover, the flexibility of the model allows teachers and students to use the Learning Activity Plan in a customised and adjusted manner that suits their own agendas and contributes to the development and improvement of the approach. It is also important to stress that this learning path needs to be collaborative throughout the Plan, albeit to different degrees in the various stages. This collaborative work between the teacher (both expert and linguist) and the student can be either strictly personal or also technology-driven, supported by collaborative platforms, a good example of which is ConcepME (Silva et al. 2012), a web-based platform for conceptual model development by group editing, discussion and negotiation. This platform allows the development of many actions proposed in the Plan, in order to accomplish domain visualisation and conceptualisation. It enables teams, including domain specialists, knowledge engineers and terminologists, to build together a conceptual representation of a domain. Since this platform is free for teaching and research purposes, it is hoped that it will improve cooperation and knowledge management and contribute to the development of TerminoCLIL environments.

At present, more research, training, and experiments are being developed in CLIL contexts in Portuguese HEIs to obtain data and feedback to further develop the method presented here and to obtain an in-depth analysis of the relation between terminology and CLIL and of the ways the former may support and enhance results and teachers' performance in CLIL environments.

\section{REFERENCES}

Bloom, Benjamim Samuel. 1956. "Taxonomy of Educational Objectives: The Classification of Educational Goals". In Handbook 1 - Cognitive Domain. New York: David McKay Co. Inc.

Coyle, Do. 2008. "CLIL - A Pedagogical Approach". In Encyclopedia of Language and Education. 2nd ed., edited by Nelleke Van Deusen-Scholl and Nancy Hornberger, 97-111. New York: Springer.

Moore, Emilee, and Melinda Dooly. 2010. “'How do apples reproduce (themselves)?’ How Teacher Trainees Negotiate Language, Content, and Membership in a CLIL Science Education Classroom at a Multilingual University”. Journal of Language, Identity, and Education 9: 58-79.

Morgado, Margarida, and Margarida Coelho. 2012. "Higher Education Experiments with CLIL vs English as the Medium of Instruction: Differences, Similari- 
ties, and Lessons to Learn for the Portuguese Context”. Paper presented at the IV Cercles Seminar Five years of Bologna. Upgrading or Downsizing Multilingualism?, Universidade do Minho (Braga, Portugal), April 26-28, 2012. [19/05/2016]. https://issuu.com/lgooliveira/docs/margaridamorgado. margaridacoelho_1a.

Morgado, Margarida, Manuel Silva, Alexandra Albuquerque, et al. 2015. "CLIL in Portuguese Higher Education - Building a Community of Practice and Learning". En Experiências de inovação didática no Ensino Superior, 65-79. Lisboa: Gabinete do Secretário de Estado do Ensino Superior, Ministério da Educação e Ciência.

Silva, Manuel, Alexandra Albuquerque, Margarida Morgado, Margarida Coelho, Maria del Carmen Arau Ribeiro, Graça Chorão, Suzana Cunha, Ana Gonçalves, Ana Isabel Carvalho, Mónica Régio, Sónia Faria, and Isabel Chumbo. 2015. CLIL Training Guide - Creating a CLIL Learning Community in Higher Education. Santo Tirso: De Facto Editores. [19/05/2016]. http://paol. iscap.ipp.pt/recles/index.php/publicacoes.

Silva, Manuel, Rute Costa, and António Soares. 2012. "Supporting Collaboration in Multilingual Ontology Specification: The Conceptme Approach”. In Proceedings of the Workshop on Challenges to Knowledge Representation in Multilingual contexts. TKE 2012, edited by Rute Costa, Manuel Silva, and António Lucas Soares. Madrid: Universidad Politécnica de Madrid. 